DOI: 10.1515/auseur-2015-0013

\title{
Language Politics and Language Rights on the Territory of Former Yugoslavia the Today's Serbia/Vojvodina
}

\author{
György SZERBHORVÁTH
}

Institute for Minority Studies, Hungarian Academy of Sciences

\begin{abstract}
In this paper, we will attempt to outline the process of how the nationality/minority rights, especially the minority language rights, were changed in the former Yugoslavia in the next period of times: ... and how they have changed in Serbia since 1990, and in Vojvodina. We present the most significant constitutional and legal changes, their impact on the institutional and everyday life, and the language policy tendencies.

Finally, we discuss how the formation of the Serbian National Councils have shaped the linguistic rights of minorities in Vojvodina, in particularly after 2009, through examining the work, experiences, and the strategy of the Hungarian National Council and the Hungarians living there.
\end{abstract}

Keywords: Serbia, Yugoslavia, Vojvodina, autonomy, minority, language policy

\section{Without Minorities}

Since its formation, the Kingdom of Serbs, Croats, and Slovenes (1918), which was named Yugoslavian Kingdom between 1929 and 1941, followed an assimilating minority policy and strongly preferred the Serbo-Croatian language. In the meantime, a different situation emerged gradually in Tito's south Slavic state.

It consisted of six federal republics and two autonomous provinces that belonged to Serbia. The federal republic became more decentralized over time. This meant that, although the official language of the federal institutions (the party headquarters, military, police) was the Serbo-Croatian, or the Croatian-Serbian, the republics and provinces could determine themselves their official languages, while in the provinces the minorities' languages became official languages (Albanian in Kosovo, Hungarian, Romanian, Slovak, and Rusyn - besides the Serbo-Croatian - in Vojvodina). This was particularly true in municipalities where a certain minority group was at higher rates. 


\section{Minority and Language Policy of the Socialist Federal Republic of Yugoslavia (1945-1990)}

One of the aims of Tito's policy was precisely to build a new nation, called the Yugoslav, and thus to create a supranational society. In 1954, the so-called Novi Sad Agreement declared that both languages, the Serbian and the Croatian, should be equally considered in the everyday use. As a result of this attempt to unify the two languages, the so-called Serbo-Croatian, or Croatian-Serbian language was created (see Radovanović 2004). And it was due to the radio and television stations that a standardized version of the Serbo-Croatian was created. (Although eventually each republic and province had its own radio and television stations and newspapers, they presented each other's news programmes and shows. But the standard version of the Serbo-Croatian language was mostly spread through the programmes, films, and sports programmes of the unified Yugoslav Radio Television. In addition, Slovenes, Macedonians, and even peoples of the South Slavic ethnic groups like the Albanians or the Hungarians and the other minorities learned the language (or at least understood it) rather and primarily from the YRT shows and newspapers than in the school.)

In the case of young people, the military became a linguistic melting pot and the youth work action (Omladinske radne akcije) also mattered in this question. The prestige of the Serbo-Croatian language grew, but after 1991 its meaning changed in a specifically negative way, it has almost meant a swear-word (PožgajHadži, Balažić Bulc Miheljak 2013, 37-66).

The 1974 Yugoslav Constitution contains the main and positive changes. ${ }^{1}$ It stresses that everyone is equal before the law, regardless of nationality, race, sex, language, religion, educational level, or social status. ${ }^{2}$ Article 170 also includes that 'all Citizens shall be guaranteed the right to opt for a nation or nationality, to express their national culture, and to use their language and alphabet freely'.

Article 171 is even clearer: 'Members of nationalities shall, in conformity with the constitution and statute, have the right to use their language and alphabet in the exercise of their rights and duties and in proceedings before state agencies and organizations exercising public powers. Members of the nations and nationalities of Yugoslavia shall, on the territory of each Republic/Autonomous Province, have the right to instruction in their own language in conformity with statute.'

The 1974 Constitution, Article 214 also stresses that 'Not speaking the language in which the official proceedings are taking place cannot be an obstacle for the

1 Službeni list SFRJ, 3 (1974), February 21, 1974. See the parts concerning the minorities and language of: Ustav Socijalističke Federativne Republike Jugoslavije 1974 (February 21, 1974) http://dediserver.eu/hosting/ethnodoc/data/YU19740221-2.pdf. Article II, Chapter III, Section 154. 
citizens and organizations to exercise and protect their rights and interests. (...) Everyone has the right to use their own language before the court or other public authorities and to access information in their own language in judicial proceedings.'

Practically, in the third part of the Constitution, which is about the relations between the federal states, ${ }^{3}$ the same is repeated by stressing that 'The languages and the alphabets of the nations and nationalities shall be equal throughout the territory of Yugoslavia.'

In reality, the Serbo-Croatian/Croatian-Serbian language became increasingly dominant in the everyday use due to the effect of the media and also to the communication of the companies, the military, the youth work action and cultural events, etc. However, regarding the subsequent discussions, it is important to point out that concerning sociolinguistic aspects the 1974 Federal Constitution stipulates both pronunciations, Ekavski and Ijekavski, and both scripts, Cyrillic and Latin, of the Serbo-Croatian language in the official use as equal.

In addition, minorities could request the use of their own languages at municipalities, courts, etc.; translating and interpreting services were set up. However, in practice, this did not mean that minority citizens could use their mother tongue in any situation without any obstacles. That period of time had the same problem as it is today: though minority citizens had/have the right to use their own language, in case if this was not possible, no sanctions were imposed.

If there was no interpreter in the court or the police officers and officials of the police station did not speak the language of a certain minority or in case there was no Hungarian-speaking teacher in the school, it was an infringement but did not have any legal and practical consequences.

\section{The Autonomy of Vojvodina}

Besides the Federal Constitution, it is important to point out that the Constitution of the Socialist Autonomous Province of Vojvodina ${ }^{4}$ (created in January 30, 1974, based on the Federal Constitution) authorized the establishment of its own constitution, constitutional court, legislature, police, courts, national banks, etc., which meant a better chance to achieve the realization of minority and language rights as well. ${ }^{5}$ But in terms of our topic the important periods are the period after 1969, when the Constitution of the Socialist Autonomous Vojvodina was created and the era after

3 Odnosi u Federaciji i prava dužnosti Federacije. Part I, sections 245, 246, and 247.

4 Ustav SAP Vojvodine. Službeni list SFRJ, 1974.

5 http://www.slobodnavojvodina.com/index.php/index.php?option=com_content\&view =article\&id=349:dok-je-imala-svoj-ustav-vojvodini-je-ostajalo-90-njenog-novca\&catid=5:akcent i\&Itemid $=40$. 
1974. At this time, the authority of the Constitution of Vojvodina was extended with state power authorities as we mentioned it earlier. But still, the laws and the Constitution of the Socialist Autonomous Vojvodina - the Statute - had to be in harmony with the Serbian Constitution and the Federal Constitution and laws. Language rights essentially were not different from languages rights on federal level.

\section{Centralization and War in Serbia after 1990}

A radically different system developed after 1990, when the break-up of the federal system occurred. First, the League of Communists of Yugoslavia was dissolved at its $14^{\text {th }}$ Congress in January 1990. But already after the so-called anti-bureaucratic Serbian revolution (coup) in the fall of 1988 Serbian nationalist supporters of Milošević were brought to power in the provinces and in most of the municipalities too. From that time on, it was practically not relevant what was written in the Constitution of Yugoslavia, of Serbia, or of Vojvodina. A state of emergency was imposed in Kosovo.

The situation in Vojvodina was less tense, but the rest of the story is well known: after the outbreak of the wars in 1991, partly due to the constraints of military mobilizations, tens of thousands of minorities at military age fled from Vojvodina, mostly Hungarians and Croats. This context fundamentally determined the situation and the rights of the minorities, while from 1990, after the introduction of the multi-party system, minority rights organizations, and later on parties, were formed.

The new Serbian Constitution, ${ }^{6}$ which deprived significant laws from the provinces (state authorities such as national banks, police, constitutional court, etc.), was adopted in 1990.

It is interesting to note that, according to the first phase: 'The Republic of Serbia is a democratic State of all citizens living within it'; ${ }^{7}$ so, it does not specifically define which nation's country it talks about. And Article 8 states that: 'In the Republic of Serbia, the Serbo-Croatian language and the Cyrillic alphabet shall be officially used, while the Latin alphabet shall be officially used in the manner established by law.'

The authorities of the provinces were reduced, but in the meantime the Constitution and laws of the Socialist Federal Republic of Yugoslavia (SFRY) were still valid, and so the Serbian Constitution's provision on language use hit the Federal's.

6 Ustav Republike Srbije, 1990. Službeni glasnik RS, 1990.1. Voltaképpen cirill betúkkel kell itt jeleznünk, hiszen immár ez a hivatalos írásmód: Устав Републике Србије. (,Служббени гласник $P C$ ", број: 1/90)

7 http://unpan1.un.org/intradoc/groups/public/documents/UNTC/UNPAN019071.pdf 
The Federal Republic of Yugoslavia as the legal successor of the Socialist Federal Republic of Yugoslavia was declared by Serbia and Montenegro on April 27, 1992. Its Constitution ${ }^{8}$ does not define either on the ground of nationality whose state it is, but according to Article15: 'In the Federal Republic of Yugoslavia, the Serbian language in its ekavian and ijekavian dialects and the Cyrillic script shall be official, while the Latin script shall be in official use as provided for by the Constitution and law.'

The Serbian Law on the Official Use of Languages and Scripts was accepted on 27 July $1991 .{ }^{9}$ According to that: 'The Serbo-Croatian language is also called Serbian language (hereinafter referred to as the Serbian language) as far as its pronunciations Ekavski and Ijekavski are concerned.'

This invalidates the Constitutional provision for the binomial name of the language and lets the monomial name take its place, and thus the Serbo-Croatian language ceases to exist in the official language use. But according to experts it still exists.

\section{The Struggle of Languages, or Language Policy, in Serbia since 1991}

Ranko Bugarski writes in his work On Old Language and New Languages (Bugarski 2007, 122-127) that in terms of linguistics and communication the SerboCroatian language still exists even after the Serbo-Croatian language became four languages after 1990, so that in the respective republics the Serbian, the Croatian, the Bosnian and, from 2007, the Montenegrin became official languages.

Croatian linguist Dubravko Škiljan (Škiljan 1998, 2002) shared this opinion too. That is, the Serbian, Croatian, Bosnian, and Montenegrin are political languages, they are the dialects and variants of the Serbo-Croatian/CroatianSerbian language. So, there was only a little change in the standard version of the language.

The nationalist Croatian politics of the nineties, and later on the Bosnian politics, also sought to explore more and more archaic croatism and turcism. In fact, such specific terms and forms became mandatory in the official discourse that only the users, administrators, and citizens do not and did not understand. (For information, see: Bugarski 1995, and my review of the book: Horváth 1996.)

The struggle of languages, or the struggle for autonomous language, could be regarded as a ridiculous and irrelevant problem, but since members of the Croatian minority live in Vojvodina and they have the right to use the Croatian

8 Ustav Savezne Republike Jugoslavije. Službeni list SRJ, br.1/92, 1992.05.01.

9 Zakon o službenoj upotrebi jezika i pisama. Službeni Glasnik RS, br. 45/91. 
language (so, it is among the official languages in Subotica too) it is important what the standard Croatian language in Croatia is.

Various dictionaries were published, the Croatian Radio-Television issued a language manual in 1992 which prohibited the use of certain words, saying they were not Croatian but Serbian expressions. This went on until it became absurd: Self-proclaimed linguists began to clean the Croatian language from all 'Serbisms,' but they went from one extreme to the other and even declared some loanwords of Latin, Greek, German, English, and also Hungarian origin to be of Serbian origin (Granick 2013, 76).

But the vehement professional and lay debate on the question of how many languages we can speak about did not take place in the public discourse alone. As we will see, this problem has consequences in the practical use of language at places where the language of the South Slavs as a minority becomes official, and so they have the right to use their own language.

The Montenegrins introduced two new sounds and the letters that indicate them (since they have both the Cyrillic and the Latin as valid scripts, in the Cyrillic script, these denote the letter $c$ and the number 3 and in the Latin script the letters $s$ and $z$ ). We talk about all of this not only because it is interesting but also because this is an evidence for a symbolic battle: the Montenegrins also do everything to separate their own language.

Again, this is not merely a curiosity in Serbia, where Montenegrins were immigrated especially to Vojvodina after 1945 (mainly to replace the Germans) and although currently there is only one municipality, Kishegyes/Mali Idoš, where the Montenegrin is an official language, according to the law, Montenegrins have the right to use their mother tongue; so, in practice, this means that HungarianMontenegrin and Serbian-Montenegrin translators should work in the selfgovernment. However, there is no such expert working there (in the latter case, it is highly doubtful what would translation mean), so ad absurdum a Hungarian translates the Serbian text to Montenegrin or vice versa.

In addition, this is a very small municipality where, due to the continuous emigration, there are only ten thousand permanent residents and Montenegrins make up about $20 \%$ of them. In a larger municipality called Verbász/Vrbas where Montenegrins make up 25\% of the residents -, there is a political fight over whether to include the Montenegrin language among the official languages of the municipality or not. The Montenegrins themselves are also divided in this question because although some of them declare themselves as Montenegrins, they consider the Serbian their mother tongue. The debate (which exists within Montenegro too) about whether the Montenegrins are an independent nation or are one of the Serb tribes is a very old, or - one might say - ancient debate. The same debate is taking place about the Bunjevci and Šokci, who also live in Vojvodina, and the question is whether they are Croatians or the descendants of 
Croatian tribes or they are an independent nation or even there is an alternative which claims that they are Catholic Serbs.

Bugarski says that the best language provisions were introduced in 1974. The ones introduced in 1990-91 were somewhat weaker and the third version in 2006 was especially the worst. He thinks that the Serbian stayed as the Serbo-Croatian language (there is still no new spelling) and it changed the least, just like the socalled Croatian, Bosnian, or the Montenegrin.

The inaccurate remark that refers to experts does not mention how many times the law has been modified or that the laws on the use of minority languages are often not followed and infringements are not monitored and/or sanctioned.

The expert Ivan Klajn thinks that the Cyrillic script will become archaic. In fact, its decline began in 1918, and with reference to a newer research in 2014 he claims that $47 \%$ of the residents use the Latin script, while $36 \%$ use the Cyrillic script. One of its reasons is that in terms of English, Latin, and other foreign languages as well as in the field of mathematics, chemistry, and computer technology or even education, it could not be otherwise.

In the meantime, he argues that all official documents should be written in the Cyrillic script, but this cannot be required in the case of private texts. Cyrillic script is rather used in eastern and southern Serbia, but the process is more evident if we consider that $47 \%$ of the $20-29$-year-olds use the Latin script, while $60 \%$ of the $70-75$-year-olds use the Cyrillic script.

\section{Language Policy and Language Use after 2010}

It is not worth particularly dealing with the Milosevic era because it was considered a police state, which was disguised as parliamentary democracy, but could hardly be called a rule of law state. After his fall, a hopeful period began, which was ended by another coup: the assassination of Prime Minister Zoran Djindjic. The new nationalist government created the new Serbian Constitution ${ }^{10}$ in 2006 after the breakdown of the barely functioning Constitution of Serbia and Montenegro (declared in 2003). The Koštunica-government was highly against autonomy and could not be seen by any standards as following a minorityfriendly policy.

The constitution defines Serbia as a nation-state: 'Republic of Serbia, the Serbian people and state of all Citizens who live in it'. ${ }^{11}$

Therefore, it highlights the expression Serbian people, but the term minority is not mentioned here. However, Article 79 determines that: 'Members of national

10 Constitution of the Republic of Serbia. The official bulletin of the Republic of Serbia. No 98/2006.

11 http://www.srbija.gov.rs/cinjenice_o_srbiji/ustav_odredbe.php?id=217. 
minorities shall have a right to: expression, preservation, fostering, developing and public expression of national, ethnic, cultural, religious specificity; use of their symbols in public places; use of their language and script; have proceedings also conducted in their languages before state bodies, organizations with delegated public powers, bodies of autonomous provinces and local self-government units, in areas where they make a significant majority of population; education in their languages in public institutions and institutions of autonomous provinces; founding private educational institutions; use of their name and family name in their language; traditional local names, names of streets, settlements and topographic names also written in their languages, in areas where they make a significant majority of population; complete, timely and objective information in their language, including the right to expression, receiving, sending and exchange of information and ideas; establishing their own mass media, in accordance with the Law. ${ }^{12}$

In other words, after Serbia inherited high standards from the SFRY regarding the use of minority languages and the field of linguistic rights, practically, if not legally, the application of these rights suffered a severe setback.

Still, we can conclude that, after Serbia together with Crna Gora had ratified the European Charter for Regional or Minority Languages in 2005, the situation in many aspects became much better than in some of the neighbouring countries.

According to the first article of the Serbian Law of 1991 on the Official Use of Languages and Scripts, ${ }^{13}$ which was amended many times (last time in 2010), the official language of Serbia is the Serbian and the official script is the Cyrillic, while the Latin script is regulated. As we could see, in practice, the law fails many times concerning the script, but it contains details of other rights such as:

- Besides Cyrillic script, words can be written anywhere in Latin script as well, but words used as signals can be written only with the Latin (Section 4);

- Traffic signs of the international and main roads, place names, and geographic names should be written with Cyrillic and Latin script as well (Section 5);

- In all official proceedings, citizens have the right to use their own language (Section 6);

- The language of a national minority can become part of the official languages of the local government if the proportion of the certain minority reaches $15 \%$ in the latest census (this census was introduced only after the modification of the Serbian Law on the Official Use of Languages and Scripts in 2010). Being an official language means that members of the national minority can use their own language in official and legal matters, in communication with judicial bodies, in official and other documents, filling out ballot-papers in case of voting. In case the proportion of a minority does not reach $2 \%$ at the level of the Republic,

12 http://www.srbija.gov.rs/cinjenice_o_srbiji/ustav_odredbe.php?id=218.

13 Zakon o službenoj upotrebi jezika i pisama. Službeni glasnik, br. 45/91, 53/93, 67/93, 48/94, 101/2005 - dr. zakon i 30/2010. 
then its members can communicate through the local government in case their mother tongue is part of the official languages (Section 11). The same section provides that the member of a minority group which reaches $2 \%$ in the territory of the Republic can turn to the organizations of the Republic in their own mother tongue and they have the right to get answers in that language.

- The minorities have the right to use their name as they write it in their own language (e.g. personal documents) (Section 18).

- This applies to the place and street names, traffic signs, official notifications, and to the companies (sections 19 and 20).

- It is important that the once acquired language rights cannot be withdrawn if the proportion of the minority group decreases at the latest census under $15 \%$ on local level and $2 \%$ on republic level.

Part $\mathrm{V}$ of the law regulates the control of these language rights: the public institutions responsible for administrative, public traffic, urban and communal, education, cultural, and healthcare services are responsible for respecting language rights provisions as well (Art. 22). For the violation of language use provisions the law envisages a fine ranging between 1,000 dinars (cca 8 euros) and 1 million dinars (cca 8,000 euros) depending on the offence - the gravest offences are missing traffic signs and place-name signs.

The Assembly of the Autonomous Province of Vojvodina further expanded the minority language use rights in 2003: ${ }^{14}$ for example, where a minority language is a local official language, bills issued by public firms and by suppliers (like post, electricity suppliers, etc.) shall be written in the minority language as well. Nevertheless, as practice shows, even in settlements where Hungarian is recognized as an official language (Kishegyes/Mali Idoš), electricity bills are issued only in Serbian and in the Cyrillic script, while telephone bills are issued in Serbian and Latin script. It may be even more interesting to note that the leaders of the local government are partly the representatives of the Hungarian Alliance of Vojvodina and other members of the local council are also almost exclusively Hungarians, just like the employees of the local public service company - even though the bills of the local public service company are issued only in Serbian. It means that the law is not applied faithfully even in places where there are minority-language-speaking employees.

Art. 8 of the law offers an additional opportunity for local governments where the proportion of inhabitants belonging to a minority on the entire territory of the local government is below $15 \%$, but in one smaller administrative unit within the settlement (in a village or community) they reach $25 \%$, in which case in that area of local government the minority language can gain official status.

14 Határozat a nemzeti kisebbségek nyelvének és írásának Vajdaság Autonóm Területén való hivatalos használatával kapcsolatos egyes kérdések részletezéséról. VAT Hivatalos Lapja, Újvidék, May 22, 2003, No 8. 
Furthermore, even if the most recent census shows that the proportion of a minority population has dropped below $15 \%$, but their language was recognized as official language before, it shall remain so. Nevertheless, lawyers formulated serious criticism against the lack of respect for the equality of languages - until 2010, 'in general, there was not any equality between the status of Serbian and other official languages (the Constitution does not guarantee the principle of the equality of languages, although within the context of the prohibition of linguistic discrimination it lists specific minority rights including language rights)' (Beretka 2014, 174). According to Katinka Beretka, the legislator found a liberal solution by ignoring questions of language use in the fields of culture, media, in certain parts of education, and the public activities of private companies.

Due to recent legislative reforms and the adoption of new laws - largely motivated by Serbia's aspirations to access the European Union -, the legislative environment has improved a lot, e.g. new ombudsman institutions have been set up at national, provincial and even municipal administrative level, having competence also in claims regarding language rights. However, at national level, the ministry of minority issues was abolished and replaced by a Government Office for Human and Minority Rights, while at provincial level in Vojvodina the tasks of the Provincial Secretary for Minorities have been extended to other policy areas not related to minorities. One of the main challenges is the continuous battle for competences between the central government and the provincial government (largely depending on opposite political coalitions in power), and the central government makes serious attempts at limiting provincial competences even in the field of language rights. Till today - reinforced by the relevant decisions of the Constitutional Court -, in Vojvodina, public education (from kindergarten to university) has been still under provincial competence and the province's privileges in language rights have also been acknowledged by the Constitutional Court (Beretka 2014, 178). Another positive development was that local governments have been entitled not only to safeguard minority rights, but also to promote them - even if the term 'promotion' is a soft-law expression (Beretka 2014, 179). Today, Serbian is the only official language in 7 out of Vojvodina's 45 municipalities and seven other languages are recognized as official languages: Hungarian is an official language in 31 municipalities and in certain settlements on the territory of other 3 municipalities; Slovak is official in 10 municipalities, Romanian in 8, Rusyn in 5, Croatian, Czech, and Montenegrin are official languages in 1 municipality each. On the territory of Vojvodina, education is carried out in a minority language (or minority languages) in 539 elementary schools and 110 secondary schools - but the number of minority language students is dropping every year, which obviously also influences the number of classes functioning in the minority language. 
The relatively new law on the protection of the rights and freedoms of national minorities ${ }^{15}$ defines persons belonging to minorities as follows: 'A national minority for the purpose of this Law shall be any group of citizens of the Federal Republic of Yugoslavia numerically sufficiently representative and, although representing a minority in the territory of the Federal Republic of Yugoslavia, belonging to a group of residents having a long[-]term and firm bond with the territory of the Federal Republic of Yugoslavia and possessing characteristics such as language, culture, national or ethnic affiliation, origin or confession, differentiating them from the majority of the population and whose members are distinguished by care to collectively nurture their common identity, including their culture, tradition, language or religion.'16

The Law guarantees equal status for all citizens irrespectively of their ethnic background, and declares the freedom to choose and use personal names in the minority language, to use the mother tongue of every citizen belonging to a minority, the right to receive education in mother tongue, various rights in the field of culture and the preservation of traditions. The same law provides regulation on the creation of National Councils. Specific provisions are codified in other sectoral laws: e.g. the law on education regulates the establishment of minority education institutions. ${ }^{17}$ These legal provisions have been extended by Art. 26 of the Statute of Vojvodina Autonomous Province, which declares that besides Serbian and the Cyrillic writing at the work places of the provincial authorities, institutions, Croatian, Hungarian, Slovak, Romanian, and Rusyn languages are also in official usage. In this framework, provincial institutions may prescribe additional language criteria for their employees.

\section{National Councils and Language Issues}

From their creation in 2002, National Councils had limited competences and legitimacy since they were elected by electors - thus, their role has increased following the adoption of the new law in 2009. ${ }^{18}$ Both in 2010 and 2014 members of minorities could elect directly their National Councils and the number of the members of each national council (ranging between 15 and 35) depends on the latest census results of the population of each minority community. The new law

15 A JSZK Hivatalos Lapja 11/2002, Szerbia és Montenegró Államközösség Hivatalos Lapja, 1/2003. Alkotmányos Alapokmány és a SZK Hivatalos Közlönye 72/2009.

16 The text of the law quoted from its English translation: http://www.refworld.org/ docid/4b5d97562.html, accessed on 1 March 2015.

17 Zakon o osnovama sistema obrazovanja i vaspitanja. Službeni glasnik RS, br. 72/2009, 52/2011 i $55 / 2013$.

18 Törvény a nemzeti kisebbségek nemzeti tanácsairól [Law on the National Councils of National Minorities]. A SZK Hivatalos Közlönye, 72/2009. 
broadened also the public competences of National Councils which covers mainly four key areas: education, public media, culture, and language use. In regard to the official language use of minority languages, the National Councils have the competence to determine the traditional denomination of minority settlements and other geographic names in minority languages - in regard to those municipalities, settlements, or local communities where the given minority language is recognized as official language. National Councils may also formulate proposals to the municipalities to give official language status to a minority language, may propose to change street signs, names of institutions, municipal districts, etc. where they see a vital interest for the recognition of minority language. National Councils are also entitled to promote the use of minority language in the public authorities' offices and may propose the adoption of specific instruments, provisions to enhance the use of official minority languages and to further the translation of legal documents, laws, and other legislation into minority languages. In the field of education, National Councils may make proposals for specific textbooks to be used in schools, especially for the education of history, literature, and mother tongue.

In the case of the Hungarian National Council, both the election and the composition of the Council can be characterized by the overwhelming dominance of one political party, the Hungarian Alliance of Vojvodina, since 2002. This dominance caused some political tensions, especially regarding the selection for the leading positions of minority institutions under the administration of the National Council. Nevertheless, in the field of language policies, the Hungarian National Council proved to be rather efficient. Due to the discrepancies characterizing the use of minority languages in public life - like in the translation or dissemination of legal regulations and other information in minority languages -, the National Council started to actively monitor the practices of public institutions. There are serious problems with the implementation of existing legal standards in minority languages: according to Art. 77 of the Constitution of Serbia, every citizen has the right to ask and receive information from public authorities in his/her mother tongue, but this barely happens in the everyday life. Even in the field of education, while minorities have the right to receive secondary education in their mother tongue, there are no guarantees for the employment of teachers who speak the language of that minority. Thus, even in schools where a minority language is officially recognized as the language of education - in lack of professional minority-language-speaking teachers -, the effective implementation of minority education rights is hindered.

In order to discover such problems, the Hungarian National Council set up a language-monitoring team to control both at municipal level and in the single institutions the effective implementation of language rights. This language-monitoring team of two officials designated by the National Council systematically overview the practice of all municipalities where Hungarian 
is an official language and the three municipalities where Hungarian is only partly recognized as official language. The idea of the ten-month mission is to examine the implementation of all relevant - national, provincial, or local - legal provisions affecting the use of Hungarian language. The mission was launched in 2014; the results of this survey, however, are not yet accessible. Nevertheless, this shows that the effective implementation of legal provisions may often be incomplete and problematic and the National Councils may launch pro-active initiatives to improve the situation.

\section{Multilingualism in Vojvodina - Experiences from the Past to Present and the Language Strategy of the Hungarian National Council}

There are no reliable survey data available on the situation of multilingualism in Vojvodina today, but the results of the previous research conducted by Lajos Göncz are still relevant. Göncz (1999) identified various challenges and tendencies that characterize the use of Hungarian as a minority language since Tito's era:

- on the one hand, Hungarian has a low social prestige; it is not seen as a practical tool of communication in the everyday life (e.g. in business life, commerce, etc.). On the other hand, there are some sporadic extreme cases where speakers tend to strongly prefer Hungarian language, totally excluding Serbian language from all public communication;

- the number of minority-language speakers is steadily diminishing even among the members of the minority community;

- a deteriorated dual lingualism emerges when speakers do not speak well neither their mother tongue nor the state language;

- a special semilingualism emerges when an individual who speaks two languages does not speak any of the two languages as well as other mono-language speakers in the society (Göncz 2004, 37);

- the contrast between Hungarian-language speakers living in areas where they form a majority and those who live in diasporas is becoming more visible, especially in the individual's relation to Serbian;

- the lack of Hungarian university education for lawyers results in the strong deterioration of Hungarian translations of public documents, laws, even so much that the Hungarian versions remain incomprehensible (Göncz 1999).

The Hungarian National Council has been aware of these social changes in Vojvodina, especially keeping an eye on the lack of effective implementation of existing legal provisions on language use, adopting a special strategy paper on linguistic rights. 
The strategy was adopted in 2012 for the period of 2012-2017, and it first evaluates the existing legislation on linguistic rights. The strategy paper states that 'today a large number of legal sources regulate in details certain areas of official language usage which result often in the adoption of contradicting legal norms' (Language Strategy: 27). ${ }^{19}$ Besides serious terminological confusion characterizing this area of legislation and problems related to the hierarchy of norms, the most critical element of language rights norms is that they are in most cases merely declarative norms. This implies that the legislator does not require any concrete action for the respect of language rights or that for the violation of these norms it did not introduce sanctions or other instruments motivating local entities, authorities, and individuals to implement these norms. In addition, both the sources and motivation are missing from effectively implementing in practice the language rights recognized by the law (Language Strategy: 12).

The strategy paper calls attention to the decreasing proportion of Hungarians among public servants employed by municipalities: in 2003-2004, their number reached $14.7-14.9 \%$, while by 2010 it diminished to $12.5 \%$. Even if the law offers opportunities for the use of minority language, the real possibility for official oral communication is limited: in municipalities where Hungarians form the majority, usually all official communication is conducted in Hungarian - although the author gained contradictory experiences as well -, while in municipalities where Hungarians form a minority even the members of the Hungarian community rarely address public authorities in Hungarian. Data collected in the strategy paper shows that the number of people requiring dual-language birth certificates was dropping till 2010 (Language Strategy: 17 - the trend has changed only because Hungarian citizenship has become more easily accessible). In written communication, $24.44 \%$ of first-grade administrative procedures were conducted in Hungarian by the municipalities in 2010 , but only $0.63 \%$ of the appeals were presented in Hungarian (Language Strategy: 27). However, statistical data show that the Hungarian language was used dominantly in three municipalities where the number of first-grade procedures was significantly high: Szabadka/ Subotica (58\%), Magyarkanizsa/Kanjiza (35\%), and Zenta/Senta (93\%), while in other municipalities there were very few positive experiences in this regard. Apparently, Hungarian language can be used only where Hungarians live in absolute or relative majority and where Hungarian-speaking public servants are available as well. In regard to judicial authorities, the situation is similarly gloomy: only $8 \%$ of the local judges speak Hungarian in the province. The strategy paper underlines that 'the lack of coordinated control mechanisms does not only create insecurity but also results in inefficiency and the diminished authority of public institutions' (Language Strategy: 28).

19 Language Strategy: 27. Accessible online at: http://www.mnt.org.rs/dokumentumok/strategiak/ nyelvhasznalati-strategia-2012-2017. 
As it could be seen above, the language policies and the situation of minority language rights altered significantly in former Yugoslavia and in Serbia/Vojvodina alike. As a conclusion, it can be said that the legal framework of minority language rights offers an acceptable level of protection and a liberal approach inasmuch as persons belonging to minorities may officially use their mother tongue. But everyday practice reveals that municipalities are not offering the opportunities recognized by law - this may happen even in municipalities where a minority forms the majority. The reasons behind that are manifold, but it seems to be sure that the lack of qualified personnel and the lack of financial resources (e.g. for translation) are influential. On the other hand, even the members of minorities do not have enough information on their own rights.

\section{Bibliography}

BERETKA, Katalin. 2011. Nyelvi jogaink Szerbiában. Anyanyelv-használati útmutató. Szabadka, Magyar Nemzeti Tanács.

2014. A hatalmi szintek közötti hatáskörmegosztás problémaköre. Doktori értekezés. Győr.

BUGARSKI, Ranko. 1997. Jezik od mira do rata. Beograd: Čigoja Štampa XX vek, Sabrana del.

2005. Jezik i kultura. Beograd: Biblioteka XX vek, 147.

2009. Evropa u jeziku. Beograd: Biblioteka XX vek, 176.

2011. Lica jezika. Beograd: Biblioteka XX vek, 116.

GÖNCZ, Lajos. 1999. A magyar nyelv Jugoszláviában (Vajdaságban). Budapest: Osiris, MTA Kisebbségkutató Múhely; Újvidék: Forum.

2004. A vajdasági magyarság kétnyelvúsége. Szabadka: MTT Könyvtár 8.

GRANIĆ, Jagoda. 2013. Pogled na noviju hrvatsku standardnojezičnuj praksu.

In: Požgaj Hadži, Vesna (ed.): Jezik između lingvistike i politike: Beograd:

Biblioteka XX vek, 210: 67-89.

HORVÁTH, György. 1996. Szociolingvisztika a háború előtt és alatt. Holmi 7: 1032-1037.

ISAILOVIĆ, Neven: Ko su bili Jugosloveni? Peščanik, September 29, 2011. http:// pescanik.net/ko-su-bili-jugosloveni/.

LANGUAGE STRATEGY, 2012: Magyar Nemzeti Tanács Nyelvhasználati Stratégia 2012-2017. http://www.mnt.org.rs/dokumentumok/strategiak/ nyelvhasznalati-strategia-2012-2017.

PETROVIĆ, Jelena. 2009. Jezička pollitika i ideologija jugoslovenstva u (medju) ratom periodu. Monitor XI(1): 35-54.

POŽGAJ-HADŽI, Vesna. 2013. Jezik između lingvistike i politike: Beograd: Biblioteka XX vek, 210.k. 
POŽGAJ-HADŽI, Vesna-BALAĆIĆ Bulc, Tatjana-MIHELJAK, Vlado. 2013. Srpskohrvatki jezik iz slovenske perspektive. In: POŽGAJ-HADŽI, Vesna (ed.), Jezik između lingvistike i politike: Beograd: Biblioteka XX vek, 210: 37-65.

RADOVANOVIĆ, Milorad. 2004. Planiranje jezika i drugi spisi. Sremski KarlovciNovi Sad: Izdavačka kuća knjižarnica Zorana Stojanovića.

ŠKILJAN, Dubravko. 1998. Javni jezik. Beograd: Biblioteka XX vek.

2002. Govor nacije: Jezik, nacija, Hrvati. Zagreb: Golden Markting. 